\title{
Developing Authentic-based Instructional Materials for Writing Skill
}

\author{
Andi Kamariah \\ Universitas Negeri Makassar, Sulawesi Selatan, Indonesia \\ Djamiah Husain \\ Universitas Negeri Makassar, Sulawesi Selatan, Indonesia \\ Haryanto Atmowardoyo \\ Universitas Negeri Makassar, Sulawesi Selatan, Indonesia \\ Kisman Salija \\ Universitas Negeri Makassar, Sulawesi Selatan, Indonesia
}

\begin{abstract}
The overall aim of this study is to develop an authentic-based instructional material for writing skill. Therefore, the research applied Research and Development design and used ADDIE model which consists of five stages namely Analysis, Design, Development, Implementation, and Evaluation. A Questionnaire was given to the third-semester students in Education Department of UIN Alauddin Makassar as the instrument to find out the students' need analysis. After designing the product, the material was validated by two experts and then implemented to the students. The implementation process of the authentic-based instructional materials was done twice in a small number of students consisted 10 students as the first try out and in a large number of students consisted of 30 students as the second try out. Then, evaluation of the materials was given by the experts, the lecturers, and the students. Data were analyzed using percentages and charts. In addition, the analysis of the data shows that most students, lecturers, and the experts gave positive responses towards the developed materials. The material was revised three times by considering the comments and suggestions by the experts, lecturers, and the students. The model of the developed materials consisted of some aspects namely goal, topic, activities, approach, media, genres, content, and testing strategy. Moreover, the learning process consisted of four parts namely discussion, pre-writing, writing, and post-writing.
\end{abstract}

Index Terms - writing, authentic material, instructional material, research and development, ADDIE model

\section{INTRODUCTION}

As a foreign language, English has an important role for students in facing the global challenges. When the students have a good skill in English, they can use the language to communicate with other all over the world, since English also play the role as an international language or we can say it as Lingua Franca. As Anburaj and Christopher (2015) stated that English is one of the obligatory subjects in professional colleges, because it's considered as a language which is accepted globally and mastering English effectively is vital to surviving in today's competitive world. Moreover, they stated that English is a language which is necessary and compulsory for most people.

Talking about English, there are actually four skills should be mastered and one of them is writing skill. Writing skill can be major criteria towards the better academic position and greater educational success. In discussing the importance of writing to learning, Writing skills are the important things for communicating knowledge, especially in educational settings. The ability to communicate specifically may prove to be an achievement in life chances. On the other hand, the ability to represent oneself well on paper will help him secure a job or higher educational chances after graduation, as one will be more attentive to the significance of the quality of the presentation of his written work (Hosseini, et al, 2013). In relation to the argument, Suleiman (2000) also said that:

"Writing is a main element of language, the multidimensional nature of writing must be considered in any reading and language arts program in instructional practices, assessment procedures, and language development." (p. 155)

In addition, the ability to write well can have a good impact on the learners' lives. Writing can be an art since the artist create the masterpiece. Without the competency and practice of basic writing skills, neither proficient works of written art can be fictional nor can any lives be influenced (Currier, 2008).

However, many learners find independent writing difficult because they have to think about so many things at once. One of the main problems among students is the fact that many of them cannot develop their writing skills, mostly the ones who are making compositions in a foreign language. (Aragon, 2013) 
Moreover, there are many students find difficulty when writing because they do not know how to start writing the topic that they should choose. As Aragón (2013) concluded that students generally come to write English composition without any idea about organizing their ideas, even in their mother tongue.

To solve the problem, teachers need to be creative in involving all learners, providing appropriate feedback and support so that learners can engage with the whole writing process and be motivated to write. As Aragón, et. al. (2013) stated that teachers must take into account other strategies if they want their students to develop effective writing skills.

Teachers should create more interactive ways to teach the subject. There should be a variety of open sessions where students can express their opinions on different topics. In literature, the beauty of novels and poems should be used rather than asking students to deal with questions and answers. This way, teaching and learning of English language can be developed and be more enjoyable (Anburaj and Christoper, 2015).

Many teachers try to make their class interesting by using various methods, techniques, and materials to stimulate learning of language skills effectively. The use of authentic materials in an EFL classroom is something that many teachers have discussed in foreign language teaching in recent years.

Authentic material means the material which is actually not designed for language teaching process, but it is used in the classroom such as real newspaper reports, magazine articles, advertisements, cooking recipes, songs, and also videos. Kilickaya (2004) realized that most of the teachers in the world agree that authentic texts or materials have many advantages if it is used for the language learning process.

Teaching writing by using authentic material seems really suitable to be applied to the students of English as a foreign language as a material in writing, and also is very helpful for the students in generating and organizing their ideas in writing. It is supported by Mishan (2005) who stated that authentic texts provide the best source of rich and varied comprehensible input for language learners. Moreover, it has effects on affective factors essential to learning, such as motivation, empathy and emotional involvement and stimulate 'whole brain processing' which can result in more durable learning. By considering the condition above, the researcher thinks it is needed to develop AuthenticBased Instructional Materials for Writing Skill. Therefore, the researcher formulates the objectives of the research is o find out the model of authentic-based instructional materials for writing skill.

To avoid the research broadening, it is very important to make the limitation of some issues in which by discipline, under discipline applied linguistics which focuses on designing instructional materials for students' writing skill by the using authentic material. By content, this research deals with the English writing skill and it is specified on the Instructional materials for the writing skill improvement of English Education Students in UIN Alauddin Makassar. The researcher used authentic materials which were taken from song lyrics and comic strips from various sources. By activity, the researcher developed instructional material for students writing skill. This research combines two approaches of the research namely: qualitative and quantitative data collection to explore the situation before conducting Research and Development $(R \& D)$ where the students were treated instructional materials developed then the researcher conducted the first try out to see the students' perception and make some revisions if needed, then the researcher made revision and conduct the second try out in UIN Alauddin Makassar and large test to see the students' improvement and the effectiveness of the material in writing English by using authentic material. By location, this research was conducted in English Education Department, UIN Alauddin Makassar, South Selatan.

\section{PRevious Related Studies}

Many researchers support the use of authentic material and agree that it exposures to real language and real life, in other words, the students get advantage from being exposed to the language in authentic materials. Moreover, the authentic materials should consider the students' level of knowledge and the students should be helped by their teachers to overcome the difficulties they encounter (Tamo, 2009).

The analysis and evaluation activities of authentic material that can be useful learning and teaching tools can go on to be effective functional text writers (Maroko:2010).

The students must look for more information in magazines, books or the internet if the explanation about a specific topic was not clear enough; there is a lot of teaching material and websites related to writing that will be very helpful for them (Aragón, et. Al: 2013).

Masood (2013) also found that authentic materials are very interesting, absorbing and motivating. Change and variety is something very important for human development and upbringing. Authentic materials can serve this purpose very well. Authentic materials can, even more, be useful to those learners who intend to go to a foreign country for higher education.

Aswini and Srinivasan (2016) found that authentic materials are significant since they increase students' motivation for learning the second language. When authentic materials are used in the classroom students are exposed to real discourse. Moreover, authentic materials help learners to acquire a language better than with the use of conventional methods.

Based on the previous studies, the researcher indicates that authentic material in learning and teaching English particularly for writing skill namely writing can give effect to the students' achievement and students' interest. The studies above become the basic theories for the researcher to design material by using authentic material for students' writing skill in English as a foreign language. 


\section{LITERATURE REVIEW}

\section{A. The Concept of Writing}

Birnie (2015) said that writing is sometimes a gathering skill, when it helps us discover what we know or "collect our thoughts," it is primarily a sharing skill which involves an active process to organize and formulate the ideas on the paper so that the reader can follow the writer's message as well as in oral form.

As one of the language skills, writing is used to express ideas. Ghaith (2002) said that writing is a complex process where the writers are allowed to explore thoughts and ideas and make them visible and concrete. Writing also encourages thinking and learning for it motivates communication and makes thought available for reflection. The ideas can be examined, reconsidered, added to, rearranged, and changed when thought is written down. In writing, a writer will be involved in the process of building the large units of ideas from smaller one. They will be linked to form sentences. The sentences will also be linked to form a piece of composition.

Teaching writing is a kind of challenge for most English teachers as Maxom (2009, page 157) stated that the students should have had a chance to listen, speak and read the language to some degree when the teacher starting to get into writing. They are writing in their own words while they have also copied the information down. Students who make no effort to write anything down at beginner level may need special attention because it could be embarrassing for students to admit that they are having difficulties starting out, so the teachers need to be vigilant.

Jacob, et. al. (in Hughes, 2008) point out that in analytic scale, it has five components in writing. They are content, organization, vocabulary, language use, and mechanics. Related on the scope of study, the writer will take all of components of writing namely: (1) content which should be clear to the readers, so that the readers can understand the message that is conveyed and gained from the content of the information itself, (2) organization which includes coherence, order of important, general to specific (specific to general), chronological order, and spatial pattern, (3) vocabulary, (4) Language use which involves correct usage endpoints of grammar such as verbs, nouns and agreement. Specific nouns and strong verbs give a reader a mental image of description, and (5) mechanics which is due to punctuation, capitalization, and spelling appropriately. This aspect is also needed to be considered since it leads readers to understand or recognize immediately what the writer definitely means to express.

\section{B. The Concept of Authentic Material}

The definitions of authentic materials are quite different in literature. What is common in these definitions is exposure to real language and its use in its own community. Widowson (1990) defines an authentic material as the material which is designed for native speakers of English and used in the classroom in a way similar to the one it was designed for. For example, a radio news report brought into the classroom so students can discuss the report on traffic in the city where learners live.

Gebhard (1996) gave more examples of authentic materials that EFL/ESL teachers have used. Some of his examples, which may serve as source material for lesson planning: (1) authentic listening such as radio ads, and songs, (2) authentic visual materials such as photographs, and stamps.(3) authentic printed materials such as newspaper articles, and bus schedules, and (4) realia (real-world objects) such as coins and currency, folded paper, wall clocks, and phones.

There are some benefits in using authentic materials are: (1) giving a positive impact on learner's motivation, (2) providing authentic cultural information, (3) providing exposure to the real language, (4) relating more closely to learners ' needs, and (5) supporting a more creative approach to teaching (Kilickaya, 2004).

\section{METHODOLOGY}

\section{A. Research Design}

In this research, the researcher applied Research and Development design in order to develop instructional materials for students' writing skill by the using authentic material as stated by Gay (2006) that Research and Development is the process of researching consumer or the students' needs and then developing products specifically designed to fulfill those needs. On the other hand, Gall, et al. (2003) stated that Research and Development still plays a minor role in education. Less than one percent of education expenditures are for this purpose. This is probably one of the main reasons why progress in education has lagged far behind progress in other fields.

Then the procedure that was used in this research is based on ADDIE model which consists of: (1) analysis which was very useful in this research as the starting point to know the prior situations in order to design the product, (2) design where the researcher started to make the model based on the analysis, (3) development which consists of some points namely develop assessment instruments, develop instructional strategy, develop and select instructional materials (4) implementation which reflects the continuous modification or revision of the program to make sure maximum efficiency and positive results are obtained, and (5) evaluation which consists of two namely formative and summative. In formative evaluation, the products are typically assessed during the development or early implementation to provide information about how best to revise and modify for improvement. The formative evaluation is also helpful for pilot projects and new programs but can be used for progress monitoring of ongoing programs. Formative evaluation in this research will be held while the development of the product to make a revision of the product. The model is shown in the following diagram: 


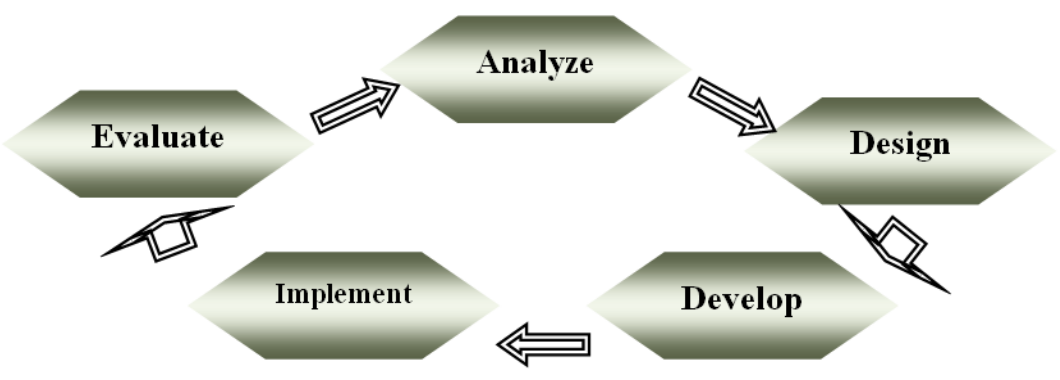

Figure 1 ADDIE Model

\section{B. Research Subjects}

The sample of the research was the third year students for academic year 2017/2018. The first try out consisted of 10 students and the second try out consisted of 30 students.

There were also involved two experts as the validators who read, evaluated, and scored the prototype. Besides, two lecturers of English Education Department, UIN Alauddin Makassar, also participated to give perception about the materials.

\section{Instrument of the Research}

There are some kinds of instruments that were used in this research namely: (1) interview where the researcher used semi-structured interview model in which the topics were selected in advance and the researcher determines sequence and wording during interview, and (2) questionnaire in which the respondents had to answer honestly what they feel about the questions or statements was used to know the respondents' perception about the instructional material developed. The questionnaire used Likert Scale that consisted of five options namely strongly agree, agree, undecided, disagree, and strongly disagree.

\section{RESULTS AND DISCUSSIONS}

\section{A. Need Analysis}

The questionnaire of needs analysis tried to find out some important information related to students which might reflect their background and their perception of the existing Writing materials.

As explained previously that the sample was the third-semester students at the age of about 18-21 years old. They consisted of 30 students of which there are 22 females and 8 males. All the students were from some regions in Indonesia and mostly from South Sulawesi. Therefore, their native languages and ethnics were based on their regions.

The level of students writing competence could be seen from their writing activities. Based on the answers on the questionnaire, there were some writing activities did by the students such as writing message like SMS, conventional letter, and electronic mail, writing a diary, writing on social media, and writing a poem. Moreover, most of students thought that they were fair in writing the idea/topic clearly, writing the idea/topic by giving examples, writing the idea/topic by providing facts, writing the idea/topic by giving reason, writing the idea/topic chronologically, and writing the idea/topic by using appropriate vocabularies. While most of them thought that they were fair and even bad in writing the idea/topic by using a good grammar. However, most of the students thought that they were good in writing the idea/topic by using appropriate capital letter and punctuation.

Related to the students' needs and interests, most of the students thought that the use media such as video, audio, picture, newspaper, and poem were useful for them. While related to the topic, Education and Holiday were the most interesting topics. Then, continued by the topics about Religion, Food, Art, Language Learning, Media, Society, Travel, and Environment. Later, the topics were used in developing the instructional material.

From the need analysis, it can be inferred Letter is the genre of writing that the students need most when the result of the students answer on the questionnaire shows that 27 students chose agree and strongly agree. The second position of the genre of writing that the students need is Description in which there were 26 students agree and strongly agree. Then, it was continued by Fiction, Non-fiction, Poem, Dialogue, News, and Essay. Moreover, there were some students giving additional genre of writing namely Argumentative and Self-experience text.

After that, the questions were continued by asking the students their preferred writing strategy. Based on the students answer on the questionnaire, most of the students chose writing in a small group was their preferred writing strategy in which there were 27 students or about $90 \%$ of them chose strongly agree and agree. Then, it was continued by writing individually in which there 25 students or about $83 \%$ of them chose to agree and strongly agree. Writing in a pair is in the third position, and then continued by writing after reading, and writing in a large group.

The questionnaire then continued by asking a question about the students preferred writing activities in which finishing a story is the students' preferred writing activities. There were 28 students or about $94 \%$ chose to finish a story as their preferred writing activities. Then, there were 27 students or about $90 \%$ of them chose to describe something and there were 26 students or about $87 \%$ of them chose to summarize and to review as their preferred writing activities. 
There were 25 students or about $83 \%$ of them agreed that writing together, telling picture, developing a title, and reviewing book are their preferred writing activities. Then, there were more than $50 \%$ of the students agreed that rearrange jumble sentences/paragraph, writing a letter, writing dialogue, and writing advertisement/poster/banner are their preferred writing activities.

At the end of the questionnaire, the researcher added some questions related to the students' learning style. The researcher considered that knowing the learning style is needed for arranging the strategies which will be used in the classroom. As Husain (2011) stated that:

"Considering of learning styles component as decisive input might help teachers overcome many pedagogical drawback, especially those not paying attention to diversity, eventually, and creativity."

From the students' answers on the categories of learning style, it can be concluded that most students' learning style was auditory, in which there $43 \%$ out of $100 \%$ of students' chose the categories of auditory learning style. Then, there were $30 \%$ of them chose visual and $27 \%$ of them chose kinesthetic learning style.

\section{B. Design and Development Phase}

Based on the need analysis and the theory of teaching Writing, the researcher offers the following model as the model of Authentic-Based Instructional Materials for Writing Skill. The new materials employed topical-based syllabus as well as the task-based syllabus. The topics are selected according to the importance of the topics to the students' lives. The materials also used task-based syllabus since each unit of the course book is design for students to do different writing tasks.

The figure below shows the model of authentic-based instructional materials for writing skill which is developed through this study. The authentic materials were selected by using some criteria namely: (1) Present real-life English, (2) Present accurate information, (3) Consist of topics of general interest such as friendship, nature, etc, (4) Present the require genres of writing such as: descriptive, procedure, etc, (5) Consists of materials which were considered to be polite in term of context, and (6) Meet the purpose of the audience (students of English Education, UIN Alauddin Makassar). Moreover, the materials were selected by considering the result of the students' need analysis which was taken before developing the model.

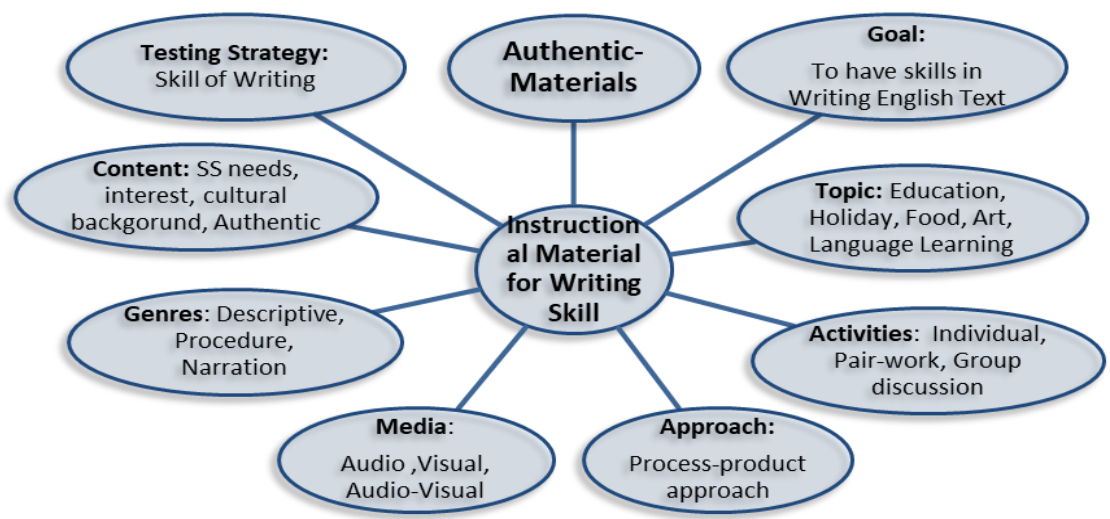

Figure 2 Model of Authentic-Based Instructional Materials for Writing Skill

As can be seen in figure 2, there are some aspects that support the instructional materials namely: goal, topic, activities, approach, media, genres, content, and testing strategy. The materials are intended to make students have competency in English writing skill especially in writing for general communication. Therefore, to achieve the goal, the instructional material consists of some units and each unit has a topic that is based on the students' interest and the type of text which is being discussed. The topics are about education, holiday, food, art, language learning, media, society, travel, and environment which are based on the students choice in the questionnaire of need analysis.

In each unit, there are some activities which are based on the stages of writing as Birnie (2015) stated namely prewriting, writing, editing, and revising. The stages of writing are done by the students individually, in pair-work, or group discussion. The materials also present some types of text in each unit namely: procedure, descriptive, recount, narration, and announcement. Each unit uses some kinds of media such as audio, visual, and audio-visual. Since the material is based on the authentic materials, the media is taken from some resources which are actually not designed for teaching but they are brought into the classroom and used in the material to teach writing. The media could be a picture, video, song, etc. Another aspect which can support the effectiveness of the instructional materials is the approach used. Therefore, this instructional material uses process approach and product approach.

Related to the focus of the research which uses authentic materials, the use of media also has an important role in this instructional material. The media used in this instructional material are audio, visual, and audio-visual such as a song, picture, and video. Moreover, the genre of writing used in this instructional is based on the students' need analysis. As explained before that there are some genres of writing that the students need such as a letter, description, fiction (narrative), non-fiction (explanation), etc. 
Overall, the content of the materials is based on the students' needs and interest which are shown in the needs analysis. Besides, the cultural background of the students is also considered as well as the use of authentic materials in the instructional materials.

Lastly, to measure this model is effective or not, we can use writing test to measure the students' skill in writing English text. The indicator of the students writing is based on the five components by Jacob namely: (1) content which refers to the idea written by the writers; (2) organization which coherence, order of important, general to specific (specific to general), chronological order, and spatial pattern; (3) language use which involves correct usage endpoints of grammar; (4) mechanics which due to capitalization, punctuation, and spelling appropriately, and (5) vocabulary.

Each unit of the instructional materials was designed to meet course objective namely the students are expected to be able to develop their writing skill in a good simple paragraph of any types using a variety of sentence types and proper vocabulary and language structure following the steps in writing process.

After designing the model of the instructional materials, then the researcher design the model of the learning process of the authentic-based instructional material for writing skill. The learning process of the Writing I subject consists of four main components namely: Discussion, Pre-writing, Writing, and Post-writing. Before doing the writing process, there is a discussion part in the instructional material to give the students chance to get prior knowledge about the text that will be related to the writing process in each chapter. The discussion also consists of the language focus that is related to the topic. In the discussion part, the students are given a chance to do some activities such as reading, discussing, and doing some activities related to the discussion.

After discussion part, the instructional material gives chance to the students to do a pre-writing activity in which can be done by some activities namely brainstorming, outlining, or generating idea based on the topic.

Then, in the writing process, the students will have a chance to write individually or in a group. Lastly, the postwriting part in the instructional material consists of some activities such as self-editing or peer-editing and revising in which the students will revise their writing based on the editing of their writing.

\section{The Expert's Validation of the Prototype}

After designing the prototype of the instructional material, the researcher asked an expert to validate the prototype before it was used in the implementation phase. The validation used a questionnaire as the instrument to see whether the prototype was applicable or not. Then the questionnaire was scored by using Likert's scale. The result of the evaluation is shown in the following figure:

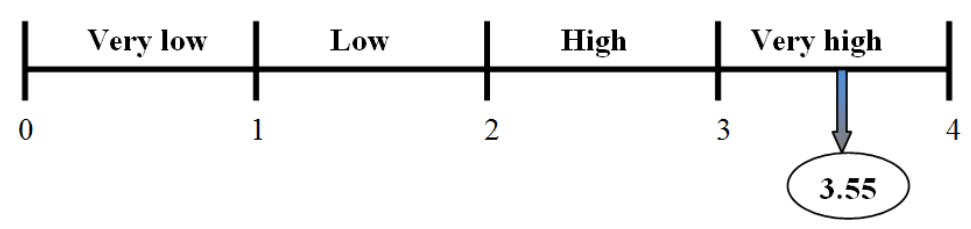

Figure 3 The level of validity of the new writing instructional materials

\section{Implementation Phase}

In this phase, the prototype of the materials was tried out to the English Education Department of IAIN Alauddin Makassar. The try out was held twice in which the first try out was held in a small number of students and the second try out was held in a large number of students.

a) First Try Out

The prototype was firstly tried out towards the small-group of students. There were ten students participated in the tryout, and at the end of the tryout, they evaluated the materials using a questionnaire of evaluation.

b) Second Try Out

After being revised, the prototype of the new writing instructional materials then tried out in a large classroom. There were thirteen students of the third-semester students of English Education Department of UIN Alauddin Makassar who joined Writing 1 course became the subjects of the tryout. Students were taught using the new writing instructional materials and also did some writing activities. After that, they were given a questionnaire to evaluate the new materials.

\section{E. Evaluation Phase}

Answering the critics and suggestions from the experts, lecturers, and students in the testing, the materials were then improved in some parts. The revisions of the product or the authentic-based instructional materials in this research were conducted in three times. Firstly, the revision was done after the expert validated the first draft. Secondly, the revision was done after the first try out in a small group. Thirdly, the revision was done after the second try out in a large group. 
TABLE 1

THE REVISIONS OF THE PROTOTYPE

\begin{tabular}{|l|l|l|l|}
\hline NO. & Categories & Comments and Suggestions & Draft \\
\hline 1. & Title of the topic & "My Best Friend" to "Describing People" & Draft 1 \\
\hline 2. & Layout & Should be colorful, not in black and white only & Draft 1 \\
\hline 3. & Content & The words "Learning Objectives" change to "Learning Goals" & Draft 1 \\
\hline 4. & Content & Correct some grammatical & $\begin{array}{l}\text { Draft 1 } \\
\text { Draft 2 } \\
\text { Draft 3 }\end{array}$ \\
\hline 5. & Content & & Draft 3 \\
\hline 6. & Worksheet & Some pictures are not familiar & Draft 3 \\
\hline 7. & Worksheet & $\begin{array}{l}\text { In the column of peer editing, add a checklist to guide the students in } \\
\text { making the editing }\end{array}$ & Draft 3 \\
\hline 8. & Learning method & The activities should be more simple since the material is Writing 1 & Draft 2 \\
\hline
\end{tabular}

Related to the students' and lecturers' perceptions which were taken by using a questionnaire that consists of some items namely the layout, learning goals, content, organization and design, students' worksheet, learning atmosphere, and the learning method, it was found that most students and lecturers gave positive perception towards the instructional materials.

Moreover, there are some comments given by the experts namely: (1) the lessons in each topic is sequenced in good order because it is organized from explanation of the topic and provide exercises or tasks from easy to difficult or simple to complex, (2) the materials will be very helpful to develop students writing skills due to process-product method, and (3) the activities are attractive.

\section{CONCLUSIONS}

Based on the research discussions, the researcher concluded that after analyzing the existing materials and students' needs it is found some information which is crucial for the new materials development namely: (a) writing instructional materials should consider the students' competence in writing, (b) writing instructional materials should consider the use of media which is appropriate with the students' level and interest, (c) the instructional materials should present some topics in which the topic should be based on the students' need and interest. The topic is important in the writing process because the topic is a determiner factor when the writer wants to develop the idea. Therefore the topic should also be based on the students' experience, (d) the instructional material should present various genres of writing such as procedure, narration, description, etc. Each type of writing also should provide the students' some activities to build their knowledge in grammar and vocabulary, (e) the instructional materials should contain writing components, (f) writing instructional materials should consider the writing strategy which is used based on the topic, (g) the instructional materials should provide some activities that can improve the skills which are needed in writing, (h) he instructional materials should present writing activities in process to make students learning writing step-by-step or from easy to difficult, (i) writing activities should be interesting to students. For that reason, instructional design should arrange tasks and activities in the ways that make students motivate to learning, such as writing together, re-arrange jumbled sentence, finishing story, etc, (j) the instructional materials should be arranged from simple to complex, (k) writing instructional materials should consider the students learning style.

Furthermore, the research also revealed the students' writing needs as they considered the following five skills as important: write the ideas of writing clearly, write the ideas chronologically or in a good order, write text using correct vocabulary, write using correct grammar and structure, and write using correct spelling and punctuation.

The model of the authentic-based instructional materials consists of some elements which are related each other namely: goal, topic, activities, approach, media, genres, content, and testing strategy. Moreover, the materials also based on the learning process model consisted of four parts of activity namely discussion, pre-writing, writing, and post-writing.

Then the researcher suggests that in developing materials, the students' needs and interests should be taken into account as the starting point. The needs analysis will be helpful for lecturers to decide the contents of the materials and the ways to present the materials. The contents of the materials should be relevant to students' daily life and the approach and methodology used should help them learn and experience the new language. Moreover, developing materials followed the phases of ADDIE will help teachers to produce effective materials that fit the students' needs and interests.

\section{REFERENCES}

[1] Anburaj \& Christopher. (2015). Barriers in Teaching English. IOSR Journal Of Humanities And Social Science (IOSR-JHSS) Volume 20, Issue 9, Ver. VI (Sep. 2015) PP 67-70

[2] Aragón, Jiménez, et. al. (2017). An Analysis of the Writing Skill Difficulties of the English Composition I Students at the Foreign Language Department of the University of El Salvador. Thesis. El Salvador: School of Arts and Sciences Foreign Language Department University of El Salvador.

[3] Aswini, P., \& Srinivasan, R. (2016). The Importance of Using Authentic Materials in Language Learning. International Journal of English Language Literature and Humanities (IJELLH); Vol. 4, Issue X, October pp.392-399 
[4] Birnie, B. F. (2015). A Teacher's Guide To Organizational Strategies For Thinking And Writing. Maryland: The Rowman \& Littlefield Publishing Group, Inc.

[5] Currier D. (2008). Essay on the importance of writing - need feedback please. Asian ESL Journal. Retrieved from Gloria, Essay Writing Feedback/EssayForum.com on 8/17/2010 Journal 80 pp. 183-199.

[6] Gall, M. D., Borg, W. R., Gall, J. P. (2003). Educational Research: an Introduction $7^{\text {th }}$ Edition. New York: Longman.

[7] Gay, L. R., et al. (2006). Educational Research Competencies for Analysis and Applications: Eight Edition. Columbus Ohio. Pearson Merril Prentice Hall.

[8] Gebhard, J.G. (1996). Teaching English as a Foreign Language: A Teacher Self-Development and Methodology Guide. Ann Arbor: The University of Michigan Press.

[9] Ghaith, Ghazi. (2002). Writing. Retrieved December 2nd, 2013, from http://www.thefreedictionary.com/writing.

[10] Hosseini, Monirosadat; Taghizadeh, Mohamad Ehsan; Abedin, Mohamad Jafre Zainol; Naseri, Elham. (2013). In the Importance of EFL Learners' writing Skill: Is there any Relation between Writing Skill and Content Score of English Essay Test?. International Letters of Social and Humanistic Sciences. 6 (2013) pp. 1-12

[11] Hughes, Arthur. (2008). Testing for Language Learners. UK: Cambridge University.

[12] Kilickaya, Ferit. (2004). Authentic Materials and Cultural Content in EFL Classrooms. The Internet TESL Journal. Retrieved on December 2nd, 2013, from http://iteslj.org/Techniques/Kilickaya-AutenticMaterial.html.

[13] Maroko, Geoffrey M. (2010). The authentic materials approach in the teaching of functional writing in the classroom. Kenya: Kenyatta University Department of English and Linguistics

[14] Masood, Asif. (2013). Exploiting Authentic Materials for Developing Writing Skills at Secondary Level. Journal of Literature, Languages and Linguistics: An Open Access International Journal Vol.1 2013 pp15-25

[15] Maxom, Michelle. (2009). Teaching English as a Foreign Language for Dummies. England: A John Wiley and Sons, Ltd, Publications.

[16] Mishan, Freda. (2005). Designing Authenticity into Language Learning Materials. UK: Intellect Books.

[17] Pasand, P. G. \& Haghi, E. B. (2013). Process-Product Approach to Writing: the Effect of Model Essays on EFL Learners' Writing Accuracy. International Journal of Applied Linguistics \& English Literature, Vol. 2 (1) PP75-79

[18] Suleiman M. F. (2000). The process and product of writing: Implications for elementary school teachers. ERIC Digest, ERIC Identifier ED 442299.

[19] Tamo, D. (2009). The Use of Authentic Materials in Classrooms. Albania: Linguistic and Communicative Performance Journal. Volume 2, PP74-78.

[20] Widdowson, H. (1990). Aspects of Language Teaching. Oxford: Oxford University Press. Retrieved December 2nd, 2013, from http://members.shaw.ca/elliottsite/pdfs/Authentic\%20Materials_\%20An\%20Overview.pdf.

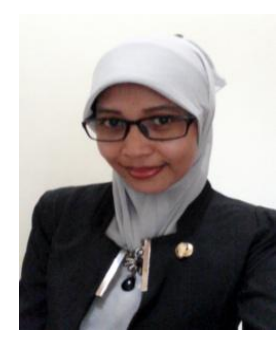

Andi Kamariah was born in Ujung Pandang, South Sulawesi, Indonesia on August 15, 1985. She is a doctoral candidate of English Education Department at the State University of Makassar. He completed his bachelor's and master's degree in English Education Department with a focus on writing skill. She is a senior teacher at Senior High School in Gowa, Sulawesi Selatan.

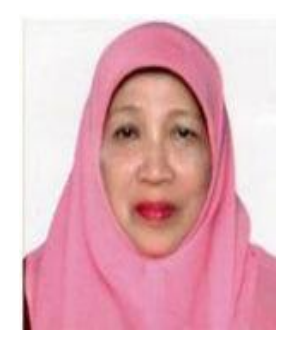

Djamiah Husain was born in Sengkang on May 5, 1948. She is a professor of English Education at English Department of State University of Makassar, Indonesia. She graduated her graduate program of English Language and Literature at IKIP Ujung Pandang, Indonesia 1976. She got her Diploma of Teaching English as a Foreign Language at English Language institute, Victoria University of Wellington, New Zealand 1993. She got her Master of English Language Studies at University of Hasanuddin, Indonesia 1999, and she completed her Doctor of English Language Studies at University of Hasanuddin, Indonesia 2003. She had been a presenter in many national and international Conferences and also she had published many articles and books. The last three books published: (1) Fostering Autonomous Learning Inside and Outside the Classroom in Language Learning, in 2011. (2) Stop Plagiarism with Mendeley, in 2016. (3) Introduction to Pragmatics, in 2017.

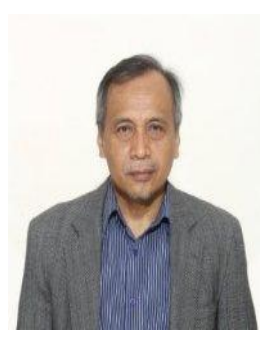

Haryanto Atmowardoyo was born in Purbalingga, Central Java, Indonesia on October 29, 1959. He is a professor of English Education at English Department of State University of Makassar, Indonesia. He obtained his doctoral degree in English Education at IKIP Jakarta in 1999. He has presented some papers in international conferences: Research Methods in TEFL; Grammatical Error in Indonesian EFL Learners' Writing (May 2007, Jakarta, Annual Linguistic Conferences of Atmajay University); A Lesson for International Journal (Hanoi, Vietnam, August 2010, the 8 the Asia TEFL Conference), Qualitative research in TEFL Studies ( Makassar, 2nd ICOLE Conference, December 2010) and Learners' Perception on the Personal and Professional Competences of Effective and Ineffective EFL Teachers (21st Century Academic Forum Conference, Harvard, University, Boston US in 2016) 


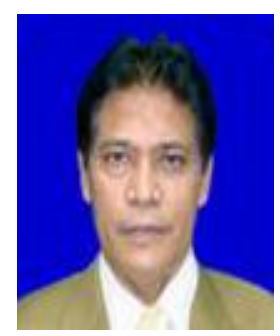

Kisman Salija was born in Enrekang, South Sulawesi, Indonesia on June 22, 1953. He is a senior lecturer in English Department of State University of Makassar, Indonesia. He obtained his doctoral degree in English Language Education at State University of Malang in 2004. He is now teaching Academic and Creative Writing Courses at undergraduate and graduate level at English Department UNM, Indonesia. His research interests are in the Teaching of Academic and Creative Writing by Indonesian young Learners English, and Language Testing. 